\title{
Hemichorea and Hemiballismus Associated with Cerebral Vascular Malformation Induced by Hyperglycemia: Case Report
} Hipergliseminin Tetiklediği Serebral Vasküler Malformasyona Bağlı Hemiballizm ve Hemikore: Olgu Sunumu

\author{
Ferda Selçuk ${ }^{1}$, Mine Hayriye Sorgun ${ }^{2}$, Süha Akpınar ${ }^{3}$ \\ 1Dr. Burhan Nalbantoğlu State Hospital, Clinic of Neurology, Nicosia, Turkish Republic of Northern Cyprus \\ ${ }^{2}$ Ankara University Faculty of Medicine, İbni Sina Hospital, Clinic of Neurology, Ankara, Turkey \\ ${ }^{3}$ Near East State University Hospital, Clinic of Radiology, Nicosia, Turkish Republic of Northern Cyprus
}

\section{Summary}

Hemichorea, hemiballismus, and hyperglycemia associated with vascular malformation is rare. We report a patient who presented with involuntary movements in the left-side with concurrent hyperglycemia. The patient had type 2 diabetes mellitus (DM) and a venous angioma in the basal ganglia on the cranial magnetic resonance imaging (MRI). A woman aged 49 years presented with flinging and throwing movements of the left upper and lower limb, which she had had for one month. Her neurologic examination confirmed involuntary, irregular, wide amplitude movements of the left limbs consistent with left hemiballismus. She had hypertension and type $2 \mathrm{DM}$. Her glucose level was $400 \mathrm{mg} / \mathrm{dL}$. Cranial MRI showed a cavernoma in the right subependymal area of the lateral ventricle and a venous angioma in the right nucleus lentiformis, which was confirmed on digital subtraction angiography. Hemiballismus improved after blood glucose level had been regulated in the follow-up period. Especially in the elderly secondary causes should be investigated in patients with acute or subacute onset of choreaballismus. We think that our patient's clinical presentation was induced by unregulated DM. Venous angioma with chorea-ballismus is rarely stated in literature and we presume the mass effect of venous angioma could be responsible of our clinical findings.

Keywords: Chorea, ballismus, vascular malformation, hyperglycemia

\section{Öz}

Vasküler malformasyona bağlı hemiballizm, hemikore ve hiperglisemi birlikteliği olgusuna az rastlanmaktadır. Biz burada başlangıç kliniği sol taraflı istemsiz hareketler olan, yapılan tetkiklerde hiperglisemi saptanan, iyi regüle edilememiş tip 2 diabetes mellitus (DM) özgeçmişi olan ve kranyal manyetik rezonans görüntülemede (MRG) bazal ganglionlar düzeyinde venöz anjiom tespit edilen bir olguyu sunuyoruz. Kırk dokuz yaşındaki kadın hasta, yaklaşık bir aydır sol kol ve sol bacakta, istemsiz, atma şeklindeki hareket şikayeti ile başvurdu. Özgeçmişinde hipertansiyon ve tip 2 DM öyküsü vardı. Hastanın muayenesinde sol taraflı, kalça ve omuzdan başlayan, şiddetli, atma şeklinde hemiballizm görüldü. Hastanın bakılan tetkiklerinde kan şekeri 400 mg/dL olarak ölçüldü. Kranyal MRG’sinde sağ nükleus lentiformis düzeyinde venöz anjiyom ve să̆ lateral ventrikül korpus lateralinde, subependimal yerleşimli, vasküler malformasyonu düşündüren lezyon tespit edildi ve ardından dijital dört damar serebral anjiyografisinde gösterildi. Takibinde kan şekeri regülasyonu sağlanan hastanın hemiballizminde tama yakın klinik düzelme oldu. Özellikle ileri yaşlı olgularda, akut veya subakut başlangıçlı kore-ballizm, özellikle sekonder nedenleri akla getirmelidir. Vasküler malformasyona bağlı hemiballizm, hemikore ve hiperglisemi birlikteliği olgusuna az rastlanmaktadır. Sunulan olguda iyi regüle edilememiş DM hastamızın kliniğinin belirmesinde kolaylaştırıcı etken olduğunu ve yine literatürde az rastlanan venöz anjiyom ve kore-ballizm birlikteliğinde, venöz anomalinin özellikle kitle etkisinin klinikten sorumlu olabileceğini düşünüyoruz.

Anahtar Kelimeler: Kore, ballizm, vasküler malformasyon, hiperglisemi 


\section{Introduction}

The term chorea, which is included in hyperkinetic disorders, means 'dance' in Greek and is used for irregular muscle contractions that are clinically random, arrhythmic, short-lived, low amplitude, sudden and jerky in nature, and involving distal parts of extremities especially, and sometimes the tongue (1). If severity and amplitude of these involuntary movements increase and involve proximal parts of extremities they are called ballismus (1). Chorea and ballismus may sometimes co-occur or follow each other (2). If they involve only one half of the body they are called as hemichorea or hemiballismus (1). Hemiballismus may sometimes occur together with other involuntary movements such as dystonia, myoclonus, or orofacial tics (2). These movements rarely occur intermittently; they are usually continuous in nature and can be interrupted by patients only for short periods of time (1). Their disappearance during sleep is characteristic. Putamen and globus pallidus are important for choreic and ballistic movements and subthalamic nucleus pathologies are especially important for ballismus (2). They can be classified as primary (neurodegenerative diseases) or secondary (autoimmune, structural, vascular, metabolic, and iatrogenic) according to the etiology (2). Late-onset cases are secondary and vascular causes are usually prominent $(2,3,5,6,7,8,9,10,11,12,13,14)$. Infarct, hemorrhage, cavernoma, and arteriovenous malformation (AVM) are among the possible vascular causes $(2,3,5,6,7,8,9,10,11,12,13,14)$. Metabolic disturbances including hyperglycemia, particularly nonketotic hyperglycemia may be associated with many neurologic disorders (4). Chorea-ballismus is among the most common of these neurologic disorders (4). Co-occurrence of hemiballismus, hemichorea, and hyperglycemia due to vascular malformation is rarely seen $(5,15,16)$. We present a woman who presented with left-sided involuntary movements. Hyperglycemia was detected in a blood analysis and she had a history of type 2 diabetes mellitus (DM). A venous angioma was detected at the level of the basal ganglia in cranial magnetic resonance imaging (MRI).

\section{Case Report}

A woman aged 49 years presented with involuntary jerks in her left arm and leg, which she had had for nearly a month. She had never been admitted to a center for these symptoms before. Her medical history was not significant except for hypertension and type 2 DM. The patient's type 2 DM was diagnosed 5 years earlier but she did not use her diabetes drugs and had not adhered to her diet for the last 6 months. With the exception of the left-sided severe hemiballismus, which started from the hip and shoulder, her physical and neurologic examinations were normal. Her laboratory analysis revealed a blood glucose of $400 \mathrm{mg} / \mathrm{dL}$. Cranial MRI showed a 10x13-mm cavernoma located subependymally on the lateral side of the ventricular corpus in the right hemisphere, which had heterogeneous signal intensity. Its periphery was hypointense, especially in T2-weighted and FLAIR sequences, and susceptibility-weighted imaging (SWI) suggested a vascular lesion (Figures 1, 2, 3). Digital 4-vessel cerebral angiography evaluation revealed findings consistent with venous angioma at the level of the left nucleus lentiformis. The patient's blood sugar was regulated in approximately 1 month. Haloperidol was stopped after 3 weeks because of a high level of somnolence. At the end of the month, near-total improvement was seen in choreiform movements. She had no active symptoms during her 2 years of follow-up. Then her left-sided choreiform movements restarted and analysis again revealed hyperglycemia. Her $\mathrm{HgbA1c}$ value was $11.2 \%$. Repeated cranial MRI revealed no significant change.

\section{Discussion}

Secondary causes should be kept in mind in acute or subacute onset chorea-ballismus in patients at advanced ages (2). These causes include drugs, vascular diseases, metabolic causes, autoimmune diseases, neoplasia, senility, and hereditary causes

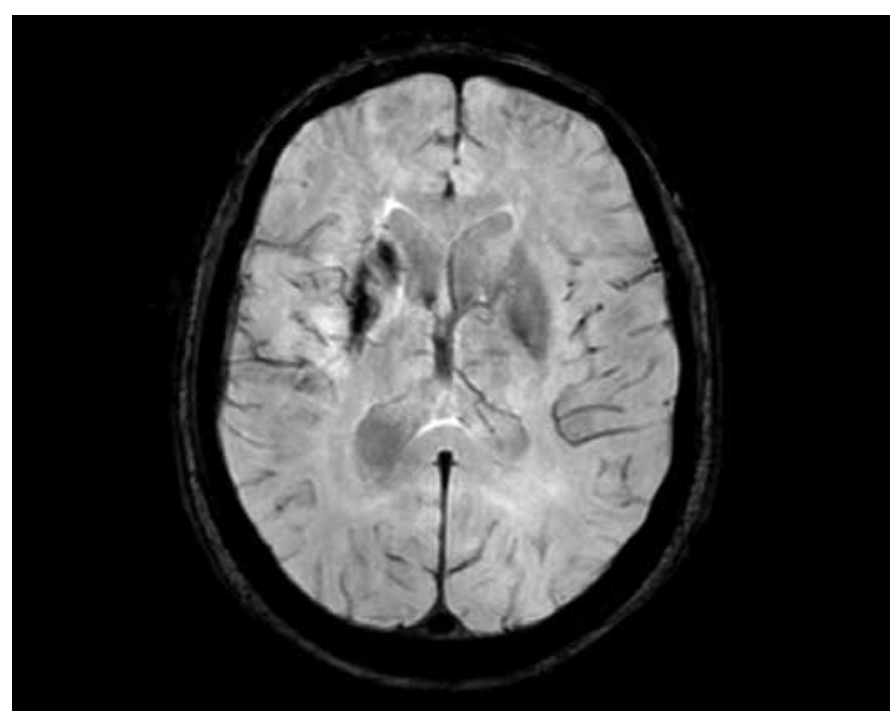

Figure 1. A hypointense lesion at the level of basal ganglia in right hemisphere consistent with vascular malformation; magnetic resonance susceptibility-weighted image

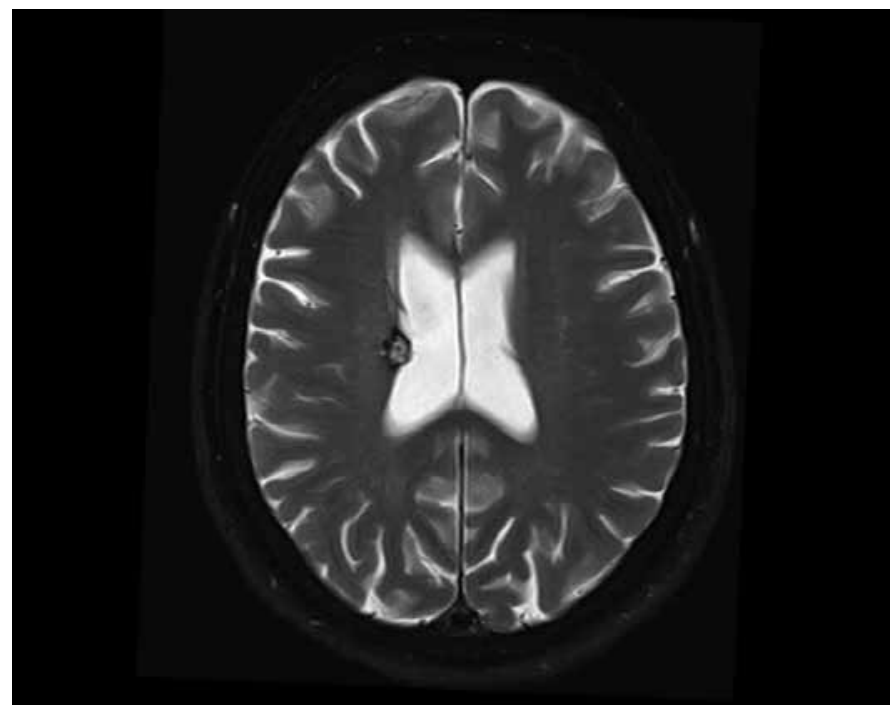

Figure 2. A subependymal cavernoma in the right hemisphere, T2weighted magnetic resonance imaging, axial section 
$(2,3,5,6,7,8,9,10,11,12,13,14)$ Hemichorea/hemiballismus is used to state presentation in on half of the body. They form approximately $0.7 \%$ of all movement disorders. They are usually associated with contralateral structural pathologies such as vascular lesions, tumors or tuberculomas, sometimes they may be associated with diabetic ketoacidosis, or non-ketotic hyperglycemia (5). Vascular etiologies that may cause chorea and ballismus include ischemic or hemorrhagic cerebrovascular events and vascular malformations $(1,2,3,5,6,7,8,9,10,11,12,13$ ,14). Vascular malformations consist of venous angiomas, AVM, and cavernous angiomas (6). Chorea due to vascular anomalies such as cerebral angioma, or cavernoma is rarely seen (7). The etiopathogenesis of chorea was tried to be explained by the disruption of balance between direct and indirect pathways. The impairment of striatal outputs that project to the globus pallidus externa (indirect pathway) increases inhibition of neurons at this region, and this decreases output of the globus pallidus externa by increasing inhibition on the globus pallidus interna. As a result, thalamocortical activity which is known to be the basic mechanism in hyperkinetic disorders develops. In the presented case, a venous angioma was detected at the level of the right nucleus lentiformis. Previous cases of chorea and ballismus associated with cavernoma have been reported $(8,9,10,11,12,13,14)$. Very rarely cases have been associated with developmental venous anomalies $(15,16)$. In these cases, venous hypo-perfusion associated with venous anomalies at the contralateral putamen level were detected. In the present case, possible hemodynamic changes due to the venous anomaly or a direct effect of the mass were thought to be responsible for the patient's clinical situation.

The second most common cause of hemiballismus after stroke is hyperglycemia $(17,18)$. Hyperglycemia associated with ballismus/chorea (HABC) is commonly seen in patients with DM aged between 50-80 years, whose blood glucose levels cannot be regulated $(19,20)$. Typically, the clinical picture settles within

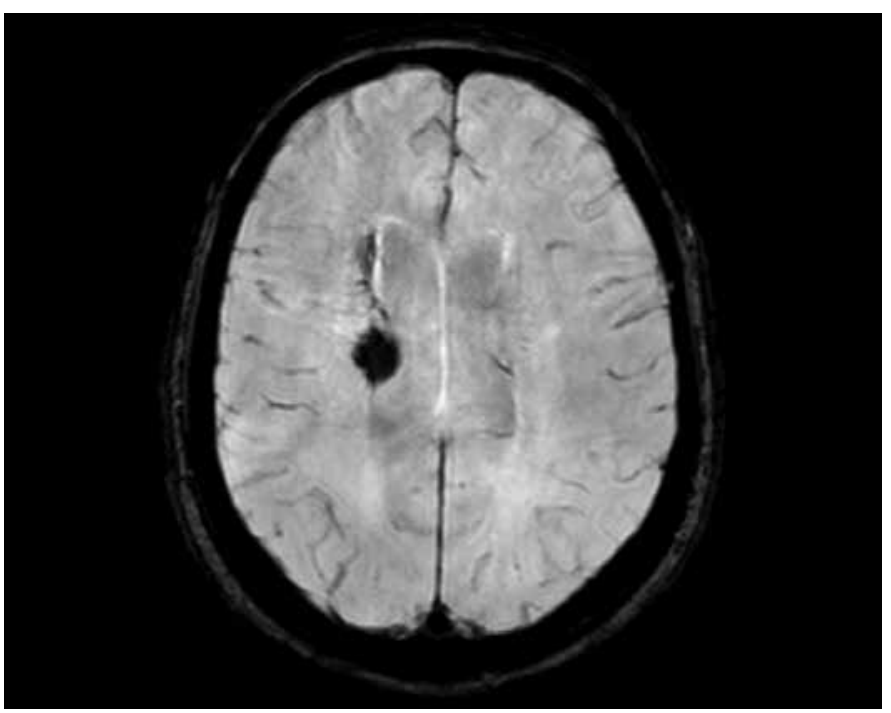

Figure 3. Image of a cavernoma in the right hemisphere and a venous malformation at its anterior, magnetic resonance, susceptibility-weighted imaging-weighted image, axial section hours. During this period the patients' blood glucose levels are between $400-1000 \mathrm{mg} / \mathrm{dL}$ and involuntary movements regress after control of hyperglycemia. Some patients have normal computed brain tomography (CBT) findings although others may have hyper-dense lesions in the basal ganglia. Cranial MRI evaluations may also be normal or they may demonstrate hyper-intense lesions in the putamen or caudate nucleus in T1weighted images and variable intensity lesions in T2-weighted images $(21,22,23)$. The pathophysiology of HABC has not yet been completely understood. Hyperglycemia may lead to tissue edema and this may increase vascular resistance and viscosity, decrease metabolic rate of neurons, inactivate Krebs cycle, and lead to consumption of gamma-aminobutyric acid (GABA) by the brain to produce energy (24). Moreover, Chang et al. (21) evaluated cranial MRI and MR spectroscopy findings of 18 patients with $\mathrm{HABC}$ and suggested that transient ischemia triggered by hyperglycemia may be responsible for the clinical picture. Shan et al. (24) suggested that ischemia triggered by hyperglycemia damages GABAergic neurons in particular, this affects the indirect pathway more prominently and thereby inhibits inhibition on the subthalamic nucleus. Additionally, hyperosmolarity decreases the epileptic threshold in the direct pathway, which increases firing of this pathway. At the end of all these processes, reactive swollen astrocytes and gliosis occur and these may cause petechial hemorrhages. This explains the hyperdensity in acute CBT. We observed no such finding in the CBT of our patient. Oh et al. (22) performed a meta-analysis of 53 cases of HABC and demonstrated hyperintense lesions at the level of the putamen in T1-weighted images in all cases. Enhancement was also seen in T2-weighted images. Additionally, in our case a hypointense lesion in T2-weighted image was detected to be a venous anomaly. In the same study by $\mathrm{Oh}$ et al. (22) in 19 of 22 patients evaluated with MRI, cranial MRI findings disappeared with improvement in chorea; blood sugar regulation was sufficient in most patients and drug treatment was given very rarely. However, in the present case diabetes regulation was combined with haloperidol.

\section{Conclusion}

In conclusion, although the present case did not fully meet the $\mathrm{HABC}$ criteria, especially with imaging findings, we believe that poorly-regulated DM precipitated the clinical picture and regulation of diabetes formed the basis of our treatment. Moreover, we suggest that the mass effect and hypo-perfusion due to venous anomaly may be responsible for the clinical picture in rare cases of comorbid venous angioma and chorea-ballismus.

\section{Ethics}

Informed Consent: Consent form was filled out by this patient. Peer-review: Internal peer-reviewed.

\section{Authorship Contributions}

Surgical and Medical Practices: Ferda Selçu, Süha Akpınar, Concept: Ferda Selcuk, Mine Hayriye Sorgun, Design: Ferda Selçuk, Mine Hayriye Sorgun, Data Collection or Processing: Ferda Selcuk, Mine Hayriye Sorgun, Süha Akpınar, Analysis or Interpretation: Ferda Selcuk, 
Mine Hayriye Sorgun, Süha Akpınar, Literature Search: Ferda Selçu, Mine Hayriye Sorgun, Writing: Ferda Selçuk, Mine Hayriye Sorgun. Conflict of Interest: No conflict of interest was declared by the authors. Financial Disclosure: The authors declared that this study has received no financial support.

\section{References}

1. Cardoso F, Seppi K, Mair KJ, Wenning GK, Poewe W. Seminar on choreas. Lancet Neurol 2006;5:589-602.

2. Fahn S, Jankovic J. Principles and Practice of Movement Disorders. Philadelphia: Churchill Livingstone/Elsevier, 2008

3. Barut BÖ, Coşkun BE, Türksoy Ö. Choreiform movement disorder secondary to intracerebral cavernoma: Case report. Turkish Journal of Neurology 2013;19:60-62.

4. Gürses C, Gökyiğit A. Metabolik ensefalopati. Öge AE, Baykan B Editörler, Nöroloji 2. Baskı içinde. Nobel Tıp Kitabevleri; 2011; s. 564-565.

5. Suchowersky O, Muthipeedika J. A case of late-onset chorea. Nat Clin Pract Neurol 2005;1:113-116.

6. Watts RL, Koller WC. Movement disorders neurologic principles and practice. Second edition. McGraw-Hill, 2004.

7. Bhidayasiri R, Truong DD. Chorea and related disorders. Post grad Med J 2004;80:527-534

8. Dörner L, Buhl R, Hugo HH, Jansen O, Barth H, Mehdorn HM. Unusual locations for cavernous hemangiomas: report of two cases and review of the literature. Acta Neurochir (Wien) 2005;147:1091-1096.

9. Donmez B, Cakmur R, Uysal U, Men S. Putaminal cavernous angioma presenting with hemichorea. Mov Disord 2004;19:1379-1380.

10. Carella F, Caraceni T, Girotti F. Hemichorea due to a cavernous angioma of the caudate. Case report of an aged patient. Ital J NeurolSci 1992;13:783-785.

11. Carpay HA, Arts WF, Kloet A, Hoogland PH, Van Duinen SG. Hemichorea reversible after operation in a boy with cavernous angioma in the head of the caudate nucleus. J Neurol Neurosurg Psychiatry 1994;57:1547-1548.
12. López-Valdés E, Posada IJ, Muñoz A, Bermejo F. Acute hemichorea caused by a cavernous angioma in the caudate. Neurologia 1998;13:205-206.

13. Yakinci C, Durmaz Y, Korkut M, Aladag A, Onal C, Aydinli M. Cavernous hemangioma in a child presenting with hemichorea: response topimozide. J Child Neurol 2001;16:685-688.

14. Kobayashi K, Aoyama N, Sasaki J, Oshima H, Fukaya C, Yamamoto T, Katayama Y. MRI appearance of a cerebral cavernous malformation in the caudate nucleus before and after chorea onset. J Clin Neurosci 2011;18:719-721.

15. Kalia LV, Mozessohn L, Aviv RI, da Costa L, Lang AE, Shadowitz S, Masellis M. Hemichorea-hemiballism associated with hyperglycemia and a developmental venous anomaly. Neurology 2012;78:838-839.

16. Civardi C, Kalia LV, Collini A, Lang AE, Aviv RI, Masellis M. Hemichoreahemiballism associated with hyperglycemia and a developmental venous anomaly. Neurology 2013;81;1181.

17. Postuma RB, Lang AE. Hemiballism: Revisiting a classic disorder. Lancet Neurol 2003;2:661-668.

18. Orhan EK, Atmaca MM, Atmaca M, Hanağası H. Chorea-Ballismus Associated with Hyperglycemia; case report. Nöropsikiyatri Arşivi 2013;50:375-378.

19. Lin JJ, Chang MK. Hemiballism-hemichorea and nonketotic hyperglycemia. J Neurol Neurosurg Psychiatry 1994;57:748-750.

20. Narayanan S. Hyperglycemia-induced Hemiballismus Hemichorea: A Case Report and Brief Review of the Literature. J Emerg Med 2010;19:1-3.

21. Chang KH, Tsou JC, Chen ST, Ro LS, Lyu RK, Chang HS, Hsu WC, Chen CM, Wu YR. Temporal features of magnetic resonance imaging and spectroscopy in non-ketotic hyperglycemic chorea-ballism patients. Eur J Neurol 2010;17:589-593.

22. Oh SH, Lee KY, Im JH, Lee MS. Chorea associated with non-ketotic hyperglycemia and hyperintensity basal ganglia lesion on T1-weighted brain MRI study: A meta-analysis of 53 cases including four present cases. J NeurolSci 2002;200:57-62.

23. Ahlskog JE, Nishino H, Evidente VG, Tulloch JW, Forbes GS, Caviness JN, Gwinn-Hardy KA. Persistent chorea triggered by hyperglycemic crisis in diabetics. Mov Disord 2001;16:890-898.

24. Shan DE, Ho DM, Chang C, Pan HC, Teng MM. Hemichorea-hemiballism: An explanation for MR signal changes. Am J Neuroradiol 1998;19:863-870 